\title{
Evaluation of Growth and Yield of Purple Coneflower (Echinacea purpurea L.) in Response to Biological and Chemical Fertilizers
}

\author{
Reza Isazadeh Hajagha ${ }^{1}$, Saliha Kirici ${ }^{1}$, Leila Tabrizi ${ }^{2}$, Ahmad Asgharzadeh $^{3} \&$ Aydin Hamidi $^{4}$ \\ ${ }^{1}$ Department of Agronomy-Medicinal Plants, Faculty of Agriculture, University of Cukurova, Turkey \\ ${ }^{2}$ Department of Horticultural Sciences, Faculty of Agricultural Science and Engineering, College of Agriculture \\ and Natural Resources, University of Tehran, Karaj, Iran \\ ${ }^{3}$ Soil and Water Research Institute of Iran, Karaj, Iran \\ ${ }^{4}$ Seed and Plant Certification and Registration Institute, Karaj, Iran
}

Correspondence: Reza Isazadeh Hajagha, Department of Agronomy-Medicinal Plants, Faculty of Agriculture, University of Cukurova, Turkey. Tel: 98-914-312-9244. E-mail: isazadeh.reza52@gmail.com

Received: November 17, 2016

Accepted: December 22, 2016

Online Published: February 15, 2017

doi:10.5539/jas.v9n3p160

URL: http://dx.doi.org/10.5539/jas.v9n3p160

\begin{abstract}
In order to study the effects of biological and chemical fertilizers on quantitative and qualitative yields of purple coneflower, an experiment was carried out during 2010-2012. The morphological traits such as plant height, number of lateral shoots, shoot fresh and dry weight, root fresh and dry weight, number of inflorescences per plant, number of flower buds per plant, and essential oil content and yield were measured. The results showed significant effects of the treatments on the growth parameters. In the second year, the mixture of the three bacteria plus mycorrhizal inoculum improved important parameters such as shoot dry weight $(40.42 \%)$, root dry weight $(60.02 \%)$, and number of inflorescences per plant (65.68\%). Interestingly, these values were not significantly different from obtained results by the chemical fertilizers. Additionally, the essential oil content in plants treated with the mixture of the three bacteria were $152.14 \%$ and $25.11 \%$ higher than the control plants in the first and the second year, respectively. The essential oil yield in plants treated with the mixture of the three bacteria was higher than those treated with the chemical fertilizers in two years. The results indicate that using biological fertilizers is a good choice to reduce the use of chemical fertilizers as an important tool to contribute to a sustainable agriculture.
\end{abstract}

Keywords: coneflower, essential oil, biological and chemical fertilizer, morphological traits

\section{Introduction}

Purple coneflower (Echinacea purpurea L.) is an herbaceous, perennial and medicinal plant belonging to the family Asteraceae, originated in North America. Active components present in both roots and shoots of various Echinacea species exhibit antifungal, antibacterial and antiviral activity. The active components are used to make useful medicines for preventing and curing colds and respiratory diseases (Bodinet, Lindequist, Teuscher, \& Freudenstein, 2002).

Most of the active components in purple coneflower are alkamides, polysaccharides, and phenolic compounds (for example, caffeic acid and its derivatives such as cichoric acid) (Nasir, 2008). Regarding the importance and role of medicinal herbs in various industries, an important consideration in cultivation of these valuable species is increasing the biomass production without using chemicals either fertilizer or pesticide (Sharma, 2002).

A strategy for the ecological production of medicinal plants is the exploitation of biological fertilizers, which may be either bacteria (plant growth promoting rhizobacteria [PGPR]) or fungi (mycorrhizae). Azotobacter, Azospirillum, and Pseudomonas are the most important PGPR (Malik, 2011). In rhizosphere, PGPR promotes transfer and absorption of essential elements by the plant roots (Frankenberger \& Arshad, 1995).

Moreover, mycorrhizal fungi are multipurpose in agricultural ecosystems include improving physical soil properties (by extending the hyphae), chemical quality of soil (by enhancing nutrient uptake), and soil biological conditions (via soil food chain) (Cardoso \& Kuyper, 2006; Banchio, Bogino, Santoro, Torres, \& Zygadlo, 2010). It has been observed that Pseudomonas, Bacillus, and Azospirillum improved the plant growth and essential oil content in Origanum majoricum. Nagananda, Das, Bhattacharya, and Kalpana (2010) demonstrated that 
application of biological fertilizers led to the improvement of Trigonella foenum-graecum seed germination and plant growth. The results obtained by Abdul-Jaleel et al. (2007) indicated that treating Catharanthus roseus seedlings with Pseudomonas fluorescens (a PGPR) increased biomass production as well as alkaloid content under water stress.

Shaalan (2005) showed that adding biological fertilizers such as Azotobacter sp., Azospirillum sp., and Pseudomonas sp. increased Nigella sativa growth and yield parameters. Vinutha (2005) reported that inoculation of Ocimum basilicum with various Azotobacter and Glomus species led to higher biomass production, more growth rate, and higher essential oil content. Moreover, Glomus mossea increased essential oil content in Origanum vulgare (Khaosaad, Vierheilig, Nell, Zitterl-Eglseer, \& Novak, 2006), Mentha arvensis (Gupta, Prasad, Ram, \& Kumal, 2002), Coriandrum sativum, and Anethum graveolens (Kapoor, Giri, \& Mukerji, 2002a, 2002b).

There are more reports that indicate mycorrhization may change the plant growth and active ingredients (Whitefield, Richards, \& Rimmer, 2004; Freitas, Martins, \& Vieria, 2004). Shalaby, El-Gengaihi, Agina, El-Khayat, and Hendawy (1997) by studying the effects of various levels of N, P, and K fertilizers indicated that as $\mathrm{N}$ increases, coneflower growth and yields improve. Kizil and Toncer (2013) studied the effects of various forms of nitrogen on some agronomic traits of coneflower. Their results showed that various forms of $\mathrm{N}$ improved agronomic traits such as fresh and dry weights.

El-Sayed, Shalaby, El-Hanafy, and El-Razik (2012) studied the effects of N and K on coneflower (Echinacea paradoxa) growth and phytochemical content and found that the highest level of $\mathrm{N}(300 \mathrm{~kg} / \mathrm{ha}$ as ammonium sulphate) and $\mathrm{K}(100 \mathrm{~kg} / \mathrm{ha}$ as potassium sulphate) led to the highest plant height, flower fresh and dry weights. Moreover, the highest polysaccharide, cafeic acid, and alkamide contents were recorded in these plants.

Chen, Nian, and $\mathrm{Wu}$ (2007) found that $\mathrm{N}$ increased coneflower growth and yields. Berti, Wilckens, Fischer, and Hevia (2001) concluded that as K increased, echinacoside content increased in E. angustifolia. Sayed (2011) studied the effects of biological fertilizers including Azospirillum lipoferum and Bacillus megatherium on growth and phytochemicals of coneflower and indicated that they improved the plant vegetative growth and carbohydrates and alkamides contents.

In an investigation, Yousef, Khalil, and El-Said (2013) concluded that the application of biological fertilizers such as nitrobein and phosphorein increased growth, yield, and carbohydrate content of coneflower. Aghaalikhani, Iranpour, and Naghdabadi (2013) showed that the application of biological fertilizers increased the biomass production of coneflower. The biological fertilizers including nitroxin and biophosphere led to the production of the highest leaf dry matter, biological yields, root length and diameter, stem diameter, and number of lateral stems. Ashnavar, Mohammad Ali, and Akbarpour (2014) by studying the various fertilizer sources, found that yield and growth indices of coneflower were influenced. Razavinia, Aghaalikhani, and Naghdabadi (2015) studied the effects of vermicompost and urea fertilizer on quantitative and qualitative traits of coneflower. Their results showed that vermicompost have a positive effect on the production of dry matter in the stem, flower, and root. It was also effective on the number of flowers per plant and chlorophyll content. The highest root dry weight and biological yield were recorded in the plants treated with 2.9 and 3.59 tonnes of vermicompost per hectare, respectively.

Hence, this study was done to investigate the effects of chemical and biological fertilizers on quantitative and qualitative yields of purple coneflower.

\section{Materials and Methods}

\subsection{Description of the Study Area}

The experiment was conducted at Horticultural Research Station, University of Tehran, Karaj, Iran. The average annual maximum temperature of the region is $13.7^{\circ} \mathrm{C}$ with an annual rainfall of $254 \mathrm{~mm}$. Soil at the station is classified as clay-loam but in order to determine physical and chemical properties of the soil, samples were taken from the experimental land. The results are shown in Table 1.

Table 1. Physical and chemical properties of the soil

\begin{tabular}{lllllllllll}
\hline Samples & $\mathrm{pH}$ & $\mathrm{EC}(\mathrm{dS} \mathrm{m})$ & $\mathrm{OC}(\%)$ & $\mathrm{N}(\%)$ & $\mathrm{P}(\mathrm{mg} / \mathrm{kg})$ & $\mathrm{K}(\mathrm{mg} / \mathrm{kg})$ & Texture & Sand $(\%)$ & Silt (\%) & Clay (\%) \\
\hline Soil & 7.78 & 2.68 & 1.19 & 0.12 & 28.6 & 360 & Loam & 39 & 38 & 23 \\
\hline
\end{tabular}

Note. $\mathrm{EC}=$ Electrical conductivity, $\mathrm{OC}=$ Organic Carbon, $\mathrm{N}=$ Nitrogen, $\mathrm{P}=$ Phosphorus, and $\mathrm{K}=$ Potassium. 


\subsection{Seed Preparation and Inoculation}

Purple coneflower seeds were obtained from Medicinal Plants Section of Department of Agronomy, University of Çukurova, Adana, Turkey. Seeds were disinfected, treated with the biological fertilizers, and then sown in $5 \times 5 \times$ 5 seed trays, which were kept in a greenhouse. To apply the biological fertilizers treatments, seeds were sterilized in sodium hypochlorite $1.5 \%$, rinsed with distilled water, and then dried at room temperature. After that, the seeds were inoculated with the inoculum of each bacterium, which had been prepared in solution. To make easier the inoculation of the mycorrhizal fungus, this was in a powder form. Arabic gum (20 $\mathrm{g}$ in one liter of water) was used. The inoculated seeds were surface-dried in shade. They were then sown in seed trays at May $4^{\text {th }}, 2011$. Additionally, the seedlings roots received the solution of the biological fertilizers right before transplanting. The trays were irrigated just after sowing. The first germinated seed was observed 7 days after sowing. The seedlings were kept in the greenhouse until producing 4-6 leaves. During this period, the land was prepared. Each plot had 6 rows, which were $50 \mathrm{~cm}$ apart. The seedlings were transplanted at July $23^{\text {th }}, 2011$ and $30 \mathrm{~cm}$ apart within each row. All of the $\mathrm{P}(60 \mathrm{~kg} / \mathrm{ha})$ and $\mathrm{K}(60 \mathrm{~kg} / \mathrm{ha})$ and half of the $\mathrm{N}(60 \mathrm{~kg} / \mathrm{ha})$ was applied in the plots in the $0-30 \mathrm{~cm}$ soil depth, which were then mixed thoroughly. The other half of the $\mathrm{N}(60 \mathrm{~kg} / \mathrm{ha})$ was applied at stemming stage. In the second year, the application of the chemical fertilizers was done according to the first year. The land was drip-irrigated during cultivation.

\subsection{Treatments and the Experimental Design}

The treatments included control (no fertilizer), chemical fertilizers (NPK), inocula of nitrogen-fixing bacteria (Azospirillum lipoferum (A.L.) and Azotobacter chrococum (A.C.)), inoculum of phosphate solubilising bacteria (Pseudomonas fluorescens (P.F.)), inoculum of mycorrhizal fungus (Glomus intraradices (G.I.)), the mixture of the three bacteria (A.L.+A.C.+P.F.), and the mixture of the three bacteria plus the mycorrhizal fungi (A.L.+A.C.+P.F.+G.I.). The chemical fertilizers were urea $46 \%$ (as source of N), triple superphosphate (as source of $\mathrm{P}$ ) and potassium sulphate (as source of $\mathrm{K}$ ). The pots with different treatments were arranged in a randomized complete block design (RCBD) with three replications of each treatment during 2010-2012.

\subsection{Harvest and Measurement of Growth and Yield Parameters}

To study the growth and phytochemical properties, samples were taken from the plants at $50 \%$ flowering (October 8, 2011 and May 4, 2012, first and second year, respectively); the border plants were not considered. Experiment was ended at October 25, 2011 in the first year and August 5, 2012 in the second year. Measured growth parameters were plant height, number of lateral shoots per plant, number of flower buds per plant, number of inflorescences per plant, and fresh and dry yields of aerial parts and roots. After weighing fresh shoots and roots, the samples were dried in shade. The purple coneflower's essential oil of dry root was extracted using a Clevenger for 4 hours according to the British Pharmacopoeia.

\subsection{Data Analysis}

SAS software was used to analyse the data, and Duncan's multiple range test $(\mathrm{P}<0.05)$ to compare the means. Furthermore, using excel, we did some calculations and drew the charts and graphs.

\section{Results}

Results of variance analysis for growth and yield parameters and essential oil content and yield are shown in Tables 2 and 3, respectively. The influence of all the treatments was significant on every growth parameter and phytochemical composition (Tables 2 and 3 ).

Table 2. Results of variance analysis for growth and yield parameters and essential oil content and yield as affected by the treatments in the first year

\begin{tabular}{llllllllllll}
\hline SOV & DF & SH & NLSP & NIP & NFBP & APFY & APDY & RFY & RDY & EOCDR & EOY \\
\hline R & 2 & 14.775 & 0.320 & 0.150 & 0.084 & 0.098 & 0.010 & 0.040 & 0.002 & 0.00003 & 0.035 \\
$\mathrm{~T}$ & 7 & $13.246^{* *}$ & $1.075^{* *}$ & $1.932^{* *}$ & $5.918^{* *}$ & $7.280^{* *}$ & $0.466^{* *}$ & $1.387^{* *}$ & $0.098^{* *}$ & $1.0005^{* *}$ & $0.462^{* *}$ \\
$\mathrm{E}$ & 14 & 0.695 & 0.068 & 0.276 & 0.557 & 0.004 & 0.0004 & 0.003 & 0.0001 & 0.00006 & 0.036 \\
$\mathrm{CV}(\%)$ & - & 1.447 & 5.367 & 8.173 & 11.115 & 0.623 & 0.829 & 1.350 & 0.923 & 21.355 & 21.688 \\
\hline
\end{tabular}

Note. $\mathrm{SH}=$ slant height, $\mathrm{NLSP}=$ number of lateral shoots per plant, NIP $=$ number of inflorescences per plant, $\mathrm{NFBP}=$ Number of flower buds per plant, APFY $=$ aerial parts fresh yield, APDY $=$ aerial parts dry yield, RFY $=$ root fresh yield, RDY = root dry yield, EOCDR $=$ essential oil content of dry root, EOY = essential oil yield, SOV $=$ source of variation, $\mathrm{DF}=$ degree of freedom, $\mathrm{R}=$ replication, $\mathrm{T}=$ treatment, $\mathrm{E}=$ error, $\mathrm{CV}=$ coefficient of variation and $* *=$ statistical significance at $99 \%$ confidence interval. 
Table 3. Results of variance analysis for growth and yield parameters and essential oil content and yield as affected by the treatments in the second year

\begin{tabular}{llllllllllll}
\hline \multicolumn{10}{c}{ Sum of squares } \\
\hline SOV & DF & SH & NLSP & NIP & NFBP & APFY & APDY & RFY & RDY & EOCDR & EOY \\
\hline R & 2 & 66.010 & 0.105 & 5.411 & 15.135 & 0.337 & 0.021 & 0.075 & 0.007 & 0.0002 & 0.689 \\
T & 7 & $49.594^{* *}$ & $0.961^{* *}$ & $56.166^{* *}$ & $14.913^{* *}$ & $45.259^{* *}$ & $2.689^{* *}$ & $6.912^{* *}$ & $0.495^{* *}$ & $1.001^{* *}$ & $3.221^{* *}$ \\
E & 14 & 2.001 & 0.025 & 0.470 & 0.575 & 0.015 & 0.0009 & 0.003 & 0.0003 & 0.0004 & 0.128 \\
CV (\%) & - & 1.317 & 1.585 & 3.124 & 5.523 & 0.516 & 0.516 & 0.700 & 0.748 & 13.000 & 12.490 \\
\hline
\end{tabular}

Note. $\mathrm{SH}=$ shoot height, NLSP $=$ number of lateral shoots per plant, NIP $=$ number of inflorescences per plant, $\mathrm{NFBP}=$ Number of flower buds per plant, $\mathrm{APFY}=$ aerial parts fresh yield, $\mathrm{APDY}=$ aerial parts dry yield, RFY $=$ root fresh yield, $\mathrm{RDY}=$ root dry yield, $\mathrm{EOCDR}=$ essential oil content of dry root, EOY $=$ essential oil yield, $\mathrm{SOV}$ = source of variation, $\mathrm{DF}=$ degree of freedom, $\mathrm{R}=$ replication, $\mathrm{T}=$ treatment, $\mathrm{E}=$ error, $\mathrm{CV}=$ coefficient of variation and $* *=$ statistical significance at $99 \%$ confidence interval.

\subsection{Plant Height and Number of Lateral Shoots per Plant}

Results of mean comparisons of coneflower's growth parameters are shown in Tables 4 and 5. The plant height changed according to years. The highest plant height in the first year was observed in $G$. intraradices treatment, which was, however, not significantly higher than those of chemical fertilizer-treated plants and plants treated with the mixture of the biological fertilizers (A.L. + A.C. + P.F. + G.I.). The lowest plant height in the first year, which was $9.52 \%$ lower than that of $G$. intraradices treatment, was recorded in the control plants (Table 4 ). The highest plant height in the second year was observed in chemical fertilizer-treated plants. This was, however, not statistically different from those of $G$. intraradices and the mixture of the biological fertilizers. The lowest plant height in the second year, being $10.9 \%$ lower than that of the highest plant height, was similarly observed in the control plants. Moreover, plant height in the second year was higher than in the first year regardless of treatment (Table 4). As shown in Table 4, the highest number of lateral shoots in the first year was observed in plants treated with chemical fertilizers, however with no significant difference from those of plants treated with the mixture of the three bacteria + mycorrhiza and $P$. fluorescens. The lowest number of lateral shoots per plant in the first year, being $27.80 \%$ lower than that of chemical fertilizers, was recorded for the $A$. chrococum, which had no significant difference from that of the control plants. The highest number of lateral shoots per plant in the second year was equally recorded for the mixture of the three bacteria + mycorrhiza and chemical fertilizers which was $16.72 \%$ lower than that of the control plants. The lowest number of lateral shoots per plant in the second year was observed in the control plants, which had no significant difference from that recorded for the treatment A.chrococum. This value was $14.33 \%$ lower than those recorded for the mixture of the three bacteria + mycorrhiza and chemical fertilizers (Table 4).

Table 4. Some morphological parameters of purple coneflower as affected by the treatments in the first and second year of experiment

\begin{tabular}{|c|c|c|c|c|c|c|c|c|}
\hline \multirow{2}{*}{$\begin{array}{l}\text { Treatment } \\
\text { Year }\end{array}$} & \multicolumn{2}{|c|}{$\mathrm{SH}(\mathrm{cm})$} & \multicolumn{2}{|c|}{ NLSP } & \multicolumn{2}{|c|}{ NIP } & \multicolumn{2}{|c|}{ NFBP } \\
\hline & FY & SY & FY & SY & FY & SY & FY & SY \\
\hline Control & $54.47 \mathrm{e}$ & $99.97 \mathrm{e}$ & $5.233 \mathrm{~d}$ & $15.47 \mathrm{f}$ & $5.233 \mathrm{~d}$ & $15.47 \mathrm{f}$ & $1.785 \mathrm{~g}$ & $4.599 \mathrm{~g}$ \\
\hline NPK & $59.63 \mathrm{ab}$ & $112.2 \mathrm{a}$ & $7.367 \mathrm{a}$ & $28.13 \mathrm{a}$ & $7.367 \mathrm{a}$ & $28.13 \mathrm{a}$ & $2.879 \mathrm{a}$ & $7.210 \mathrm{a}$ \\
\hline $\mathrm{AL}$ & $55.90 \mathrm{de}$ & $104.5 \mathrm{~d}$ & $6.400 \mathrm{abc}$ & $20.67 \mathrm{~cd}$ & $6.400 \mathrm{abc}$ & $20.67 \mathrm{~cd}$ & $2.154 \mathrm{e}$ & $5.450 \mathrm{f}$ \\
\hline $\mathrm{AC}$ & $55.97 \mathrm{de}$ & $105.0 \mathrm{~d}$ & $5.600 \mathrm{~cd}$ & $18.30 \mathrm{e}$ & $5.600 \mathrm{~cd}$ & $18.30 \mathrm{e}$ & $1.826 \mathrm{f}$ & $4.598 \mathrm{~g}$ \\
\hline $\mathrm{PF}$ & $57.07 \mathrm{~cd}$ & $107.1 \mathrm{~cd}$ & $6.600 \mathrm{ab}$ & $21.43 \mathrm{c}$ & $6.600 \mathrm{ab}$ & $21.43 \mathrm{c}$ & $2.394 \mathrm{~d}$ & $6.002 \mathrm{e}$ \\
\hline GI & $60.20 \mathrm{a}$ & $110.8 \mathrm{ab}$ & $5.867 \mathrm{bcd}$ & $19.83 \mathrm{~d}$ & $5.867 \mathrm{bcd}$ & $19.83 \mathrm{~d}$ & $2.531 \mathrm{c}$ & $6.287 \mathrm{~d}$ \\
\hline $\mathrm{AL}+\mathrm{AC}+\mathrm{PF}$ & $58.20 \mathrm{bc}$ & $109.0 \mathrm{bc}$ & $7.300 \mathrm{a}$ & $26.13 b$ & $7.300 \mathrm{a}$ & $26.13 \mathrm{~b}$ & $2.622 \mathrm{~b}$ & $6.603 \mathrm{~b}$ \\
\hline $\mathrm{AL}+\mathrm{AC}+\mathrm{PF}+\mathrm{GI}$ & $59.60 \mathrm{ab}$ & $110.5 \mathrm{ab}$ & $7.067 \mathrm{a}$ & $25.63 \mathrm{~b}$ & $7.067 \mathrm{a}$ & $25.63 \mathrm{~b}$ & $2.607 \mathrm{~b}$ & $6.458 \mathrm{c}$ \\
\hline
\end{tabular}

Note. $\mathrm{SH}=$ shoot height, $\mathrm{NLSP}=$ number of lateral shoots per plant, NIP $=$ number of inflorescences per plant, $\mathrm{NFBP}=$ Number of flower buds per plant, FY $=$ first year, SY $=$ second year, and NPK = nitrogen potassium phosphorus; Mean values followed by the same superscripts within a column are not significantly different at $\mathrm{p}<$ 0.01 . 


\subsection{Fresh and Dry Yield of Aerial Part}

The highest fresh yield of aerial parts in the first year was observed in plants treated with the chemical fertilizers. This value was significantly higher than the other values, e.g. 58.8\% higher than that of the control plants. The lowest one in the first year was recorded in the control plants, which had, however, no significant difference from that of A. chrococum treatment (Tables 4 and 5). Fresh yield of aerial part in the second year was affected similarly as in the first year: The highest fresh yield of aerial part, being significantly higher than the other respective values, was recorded in chemical fertilizer-treated plants, which was $58.77 \%$ higher than the value recorded for the control plants. The lowest fresh yield of aerial part in the second year observed in the control plants, which was not significantly different from that belonging to A. chrococum treatment (Tables 4 and 5). The highest dry yield of aerial part in the first year was observed in the chemical fertilizer treated plants, which were significantly higher than the other respective values, e.g. 58.35\% higher than that of the control plants. The lowest dry yield of aerial part in the first year was recorded in the control plants (Table 4). In the second year, the highest dry yield of aerial part was also observed in the chemical fertilizer treated plants, which was significantly higher than the other respective values, e.g. $56.77 \%$ higher than that of the control plants. The lowest one in the second year, being significantly lower than the other respective values, was recorded in the control plants (Table 4). The highest fresh yield of aerial parts in the first year was observed in plants treated with the chemical fertilizers. This value was significantly higher than the other values, e.g. 58.8\% higher than that of the control plants. The lowest one in the first year was recorded in the control plants, which had, however, no significant difference from that of $A$. chrococum treatment (Tables 4 and 5). Fresh yield of aerial part in the second year was affected similarly as in the first year: The highest fresh yield of aerial part, being significantly higher than the other respective values, was recorded in chemical fertilizer-treated plants, which was $58.77 \%$ higher than the value recorded for the control plants. The lowest fresh yield of aerial part in the second year observed in the control plants, which was not significantly different from that belonging to A. chrococum treatment (Tables 4 and 5). The highest dry yield of aerial part in the first year was observed in the chemical fertilizer treated plants, which were significantly higher than the other respective values, e.g. 58.35\% higher than that of the control plants. The lowest dry yield of aerial part in the first year was recorded in the control plants (Table 4). In the second year, the highest dry yield of aerial part was also observed in the chemical fertilizertreated plants, which was significantly higher than the other respective values, e.g. $56.77 \%$ higher than that of the control plants. The lowest one in the second year, being significantly lower than the other respective values, was recorded in the control plants (Table 4).

\subsection{Number of Inflorescences and Flower Buds per Plant}

The highest number of inflorescences per plant in the first year, $40.78 \%$ higher than that of the control plants, was observed in plants treated with NPK, the mixture of the three bacteria plus mycorrhizal inoculum, albeit with no significant difference from those of the chemical fertilizers, the mixture of the three bacteria, and $P$. fluorescens. The lowest number of inflorescences per plant in the first year was observed in the control plants, however with no significant difference from those of A. chrococum and G. intraradices (Table 5). Regarding to Table 5, the highest number of inflorescences per plant in the second year was recorded in the chemical fertilizertreated plant, which was significantly higher than those of the other treatments, e.g. $81.84 \%$ higher than that of the control plants. Number of inflorescences per plant in the second year was not different in plants treated with the mixture of the three bacteria plus mycorrhizal inoculum and in plants treated with the mixture of the three bacteria, but they had a better effect than the sole application of either species. Moreover, the lowest number of inflorescences per plant in the second year was observed in the control plants, which was significantly lower than those of the other treatments. The highest number of flower buds in the first year was observed in $G$. intraradices, albeit with no significant difference from those of the chemical fertilizers, A. chrococum, $P$. fluorescens and the three bacteria + mycorrhizal inoculum. The lowest number of flower buds in the first year, being $36.67 \%$ lower than that of $G$. intraradices, was observed in the control plants, which had no significant difference from those of A. lipoferum and the mixture of the three bacteria, nevertheless (Table 5), as shown in Table 5, the highest number of flower buds per plant in the second year, being $51.49 \%$ higher than that of the control plants, was observed in the chemical fertilizer treated plants, which was significantly higher than those of the other treatments. The lowest number of flower buds in the second year was recorded in A. lipoferum treated plants which, however had no significant difference from those of the control plants, or A. chrococum, P. fluorescens, or G. intraradices treated plants. 
Table 5. Some yields parameters of purple coneflower as affected by the treatments in the first and second year of experiment

\begin{tabular}{|c|c|c|c|c|c|c|c|c|}
\hline \multirow{2}{*}{$\begin{array}{l}\text { Treatment } \\
\text { Year }\end{array}$} & \multicolumn{2}{|c|}{ APFY (t/ha) } & \multicolumn{2}{|c|}{ APDY (t/ha) } & \multicolumn{2}{|c|}{ RFY (t/ha) } & \multicolumn{2}{|c|}{ RDY (t/ha) } \\
\hline & FY & SY & FY & SY & FY & SY & FY & SY \\
\hline Control & $7.242 \mathrm{f}$ & $18.12 \mathrm{~g}$ & $2.852 \mathrm{f}$ & $5.257 \mathrm{~g}$ & $2.852 \mathrm{f}$ & $5.257 \mathrm{~g}$ & $4.867 \mathrm{~b}$ & $12.10 \mathrm{~d}$ \\
\hline NPK & $11.50 \mathrm{a}$ & $28.77 \mathrm{a}$ & $4.735 \mathrm{a}$ & $9.441 \mathrm{a}$ & $4.735 \mathrm{a}$ & $9.441 \mathrm{a}$ & $7.867 \mathrm{a}$ & $18.33 \mathrm{a}$ \\
\hline $\mathrm{AL}$ & $8.609 \mathrm{e}$ & $21.64 \mathrm{f}$ & $3.485 \mathrm{e}$ & $6.905 \mathrm{e}$ & $3.485 \mathrm{e}$ & $6.905 \mathrm{e}$ & $5.167 \mathrm{~b}$ & $11.77 \mathrm{~d}$ \\
\hline $\mathrm{AC}$ & $7.267 \mathrm{f}$ & $18.21 \mathrm{~g}$ & $2.902 \mathrm{f}$ & $6.079 \mathrm{f}$ & $2.902 \mathrm{f}$ & $6.079 \mathrm{f}$ & $7.967 \mathrm{a}$ & $12.10 \mathrm{~d}$ \\
\hline PF & $9.567 \mathrm{~d}$ & $23.89 \mathrm{e}$ & $3.989 \mathrm{~d}$ & $8.331 \mathrm{~d}$ & $3.989 \mathrm{~d}$ & $8.331 \mathrm{~d}$ & $7.800 \mathrm{a}$ & $13.00 \mathrm{~cd}$ \\
\hline GI & $10.18 \mathrm{c}$ & $25.46 \mathrm{~d}$ & $4.099 \mathrm{c}$ & $8.473 \mathrm{c}$ & $4.099 \mathrm{c}$ & $8.473 \mathrm{c}$ & $8.067 \mathrm{a}$ & $13.10 \mathrm{~cd}$ \\
\hline $\mathrm{AL}+\mathrm{AC}+\mathrm{PF}$ & $10.39 \mathrm{~b}$ & $25.95 \mathrm{c}$ & $4.267 \mathrm{~b}$ & $8.937 \mathrm{~b}$ & $4.267 \mathrm{~b}$ & $8.937 \mathrm{~b}$ & $5.267 \mathrm{~b}$ & $13.83 \mathrm{c}$ \\
\hline $\mathrm{AL}+\mathrm{AC}+\mathrm{PF}+\mathrm{GI}$ & $10.47 \mathrm{~b}$ & $26.22 \mathrm{~b}$ & $4.270 \mathrm{~b}$ & $8.888 \mathrm{~b}$ & $4.270 \mathrm{~b}$ & $8.888 \mathrm{~b}$ & $6.700 \mathrm{a}$ & $15.60 \mathrm{~b}$ \\
\hline
\end{tabular}

Note. $\mathrm{APFY}=$ aerial parts fresh yield, APDY $=$ aerial parts dry yield, $\mathrm{RFY}=$ root fresh yield, RDY $=$ root dry yield, EOCDR = essential oil content of dry root, EOY = essential oil yield, FY = first year, SY = second year, and NPK $=$ nitrogen potassium phosphorus; Mean values followed by the same superscripts within a column are not significantly different at $\mathrm{p}<0.01$.

\subsection{Root Essential Oil Content and Yield}

The highest essential oil content of dry root in the second year, $0.543 \%$, was recorded in plants treated with the mixture of the three bacteria, albeit with no significant difference from that of $G$. intraradices and chemical fertizers treated plants $(0.515 \%)$. The lowest essential oil content in the first year, $0.0204 \%$, was observed in $A$. lipoferum treated plants, which did not significantly differ from those of plants treated with the mixture of the three bacteria plus mycorrhizal inoculum and P. fluorescens treated plants and control plant (Figure 1).

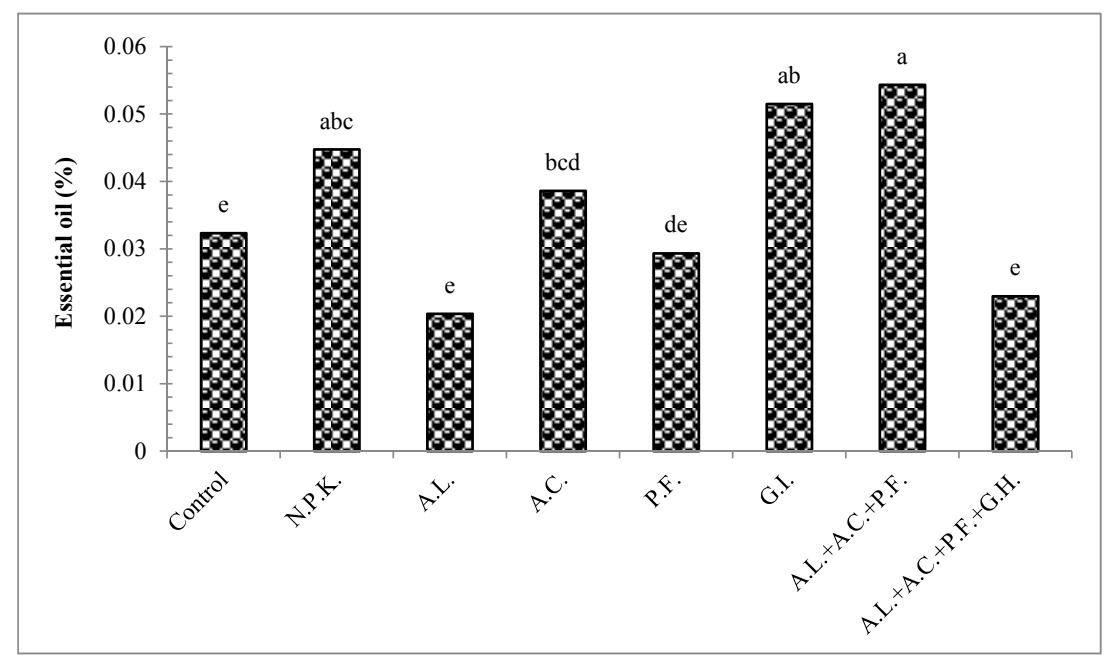

Figure 1. Essential oil content (\%) of dry root of purple coneflower as influenced by the biological and chemical fertilizers in the first year of experiment

The highest essential oil content of dry root in the second year was observed in the control plants, albeit with no significant difference from those of plants treated with A. chrococum or G. intraradices or plants treated with the mixture of the three bacteria. Essential oil content in the chemical fertilizer-treated plants in the second year was significantly lower (41.01\% lower) than that of the control plants. Furthermore, the lowest essential oil content in the second year was observed in and P. fluorescens-treated plants, being $75.40 \%$ lower than that of the control plants (Figure 2). 


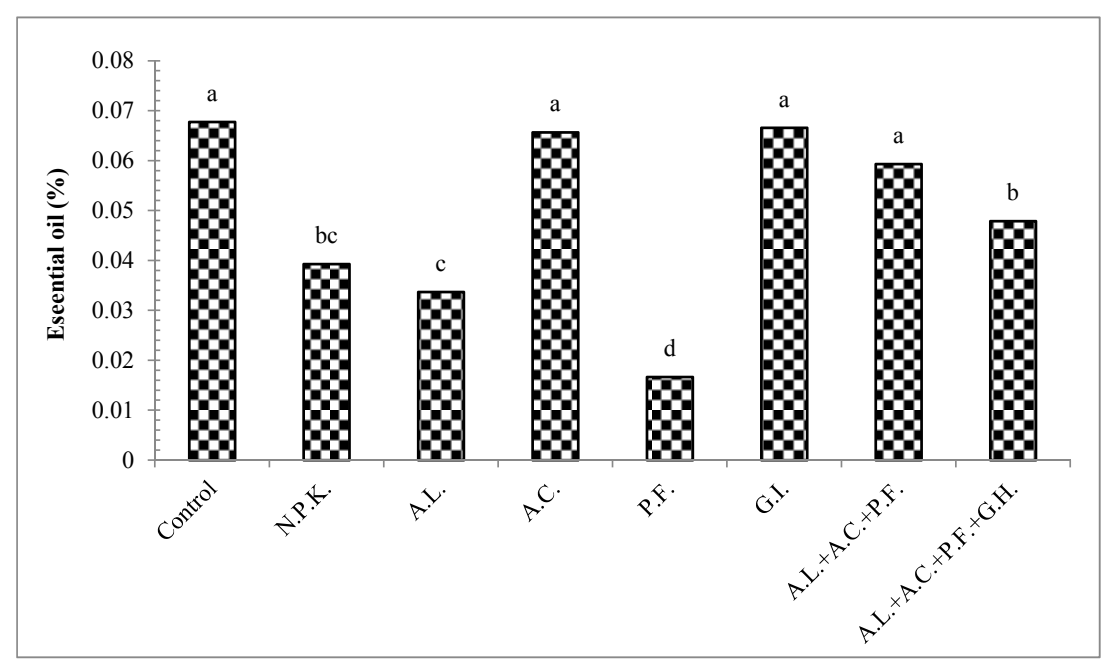

Figure 2. Essential oil content (\%) of dry root of purple coneflower as influenced by the biological and chemical fertilizers in the second year of experiment

The highest essential oil yield $(1.429 \mathrm{~kg} / \mathrm{ha})$ in the first year was observed in plants treated with the mixture of the three bacteria, which was $151.14 \mathrm{~kg} /$ ha higher than that of the control plants in the first year (Figure 3).

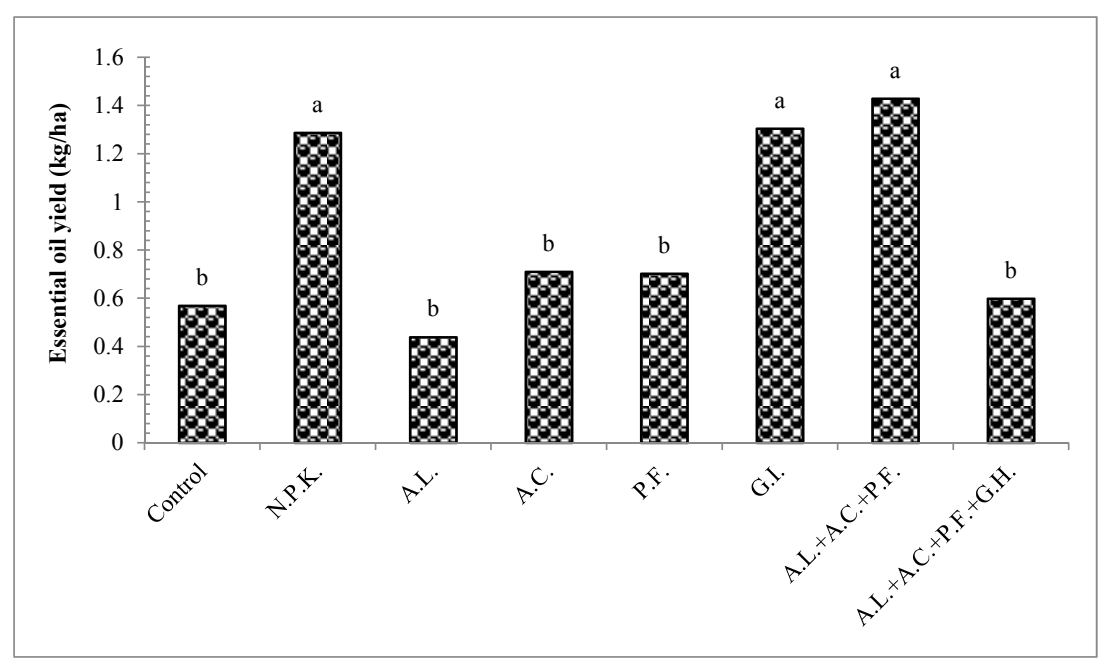

Figure 3. Essential oil yield $(\mathrm{kg} / \mathrm{ha})$ of purple coneflower affected by the biological and chemical fertilizers in the first year of experiment

The highest essential oil yield in the second year $(4.182 \mathrm{~kg} / \mathrm{ha})$ was recorded for $G$. intraradices treatment, which had no significant difference from that for the mixture of the three bacteria $(3.891 \mathrm{~kg} / \mathrm{ha})$. Furthermore, these essential oil yields were significantly $(47.77 \%$ and $37.49 \%$, respectively) higher than that recorded for the chemical fertilizer treatment (Figure 4). 


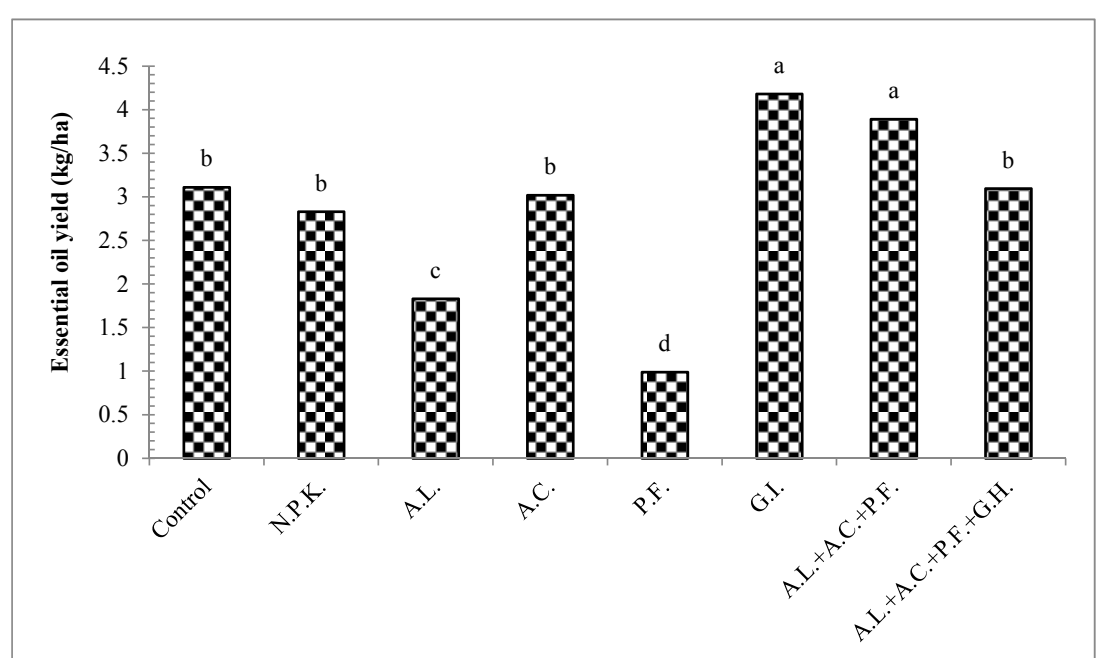

Figure 4. Purple coneflower essential oil yield (kg/ha) as influenced by the biological and chemical fertilizers in the second year of experiment

\section{Discussion}

According to the results, applying plant growth promoting rhizobacteria (PGPR) and mycorrhizal fungi enhanced growth traits and yield components in purple coneflower. The increased yield by biological fertilizers could be due to the fact that they improve activity of beneficial soil microorganisms as well as soil structure, thereby providing water and micro/macronutrients for the plant (Darzi, 2006). Although the highest root and shoot fresh and dry weights were obtained by applying chemical fertilizers, these values did not have any significant difference from the values obtained by treating plants with the mixture of the three bacteria plus mycorrhizal inoculum. Shoot and root biomass of purple coneflowers treated with the biological fertilizers were considerably higher than those of the control plants, and in this case, the biological fertilizers were able to compete with the chemical fertilizers. In the first and second year, shoot dry yield of the plants treated with the mixture of three bacteria plus + mycorrhizal inoculum was $46.04 \%$ and $40.42 \%$ higher than those of the control plants, respectively. Additionally, root dry weights obtained by this treatment in the first and second year were higher than those of the control plants by $43.87 \%$ and $61.02 \%$, respectively. The superiority of the mixture of the three bacteria plus mycorrhizal inoculum in these traits is due to increased soil microbial biomass which enhanced production of plant growth regulators, and also improved availability of nutrients especially $\mathrm{N}$ and $\mathrm{P}$. Indeed, the photosynthesis rate, growth, number of shoots, and, in turn, number of flowers were increased. Shaalan (2005) concluded that soil fertilization by biological fertilizers such as Azotobacter, Azospirillum, and Pseudomonas species has led to the improvement of growth and yield components of Nigella sativa. In a study on Withania somnifera, Kumar, Singh, and Sharma (2009) reported that applying Azotobacter and Pseudomonas species together with manure had a positive influence on yield and commercial indices. Kandeel, Menesy, Khalafalla, and Gad (2004) in their study on Foeniculum vulgare demonstrated that using PGPR, resulted an increase in plant height, shoot and root dry and fresh weights.

PGPR fixes nitrogen, balance the uptake of macro/micronutrients and release amino acids, antibiotics, HCN, and siderophore. In fact PGPR improves plant growth and development. Additionally, they enhance plant growth and yield by producing growth promoting hormones, especially auxins, gibberellins and cytokinins through increasing the availability of nutrients and by improving seed germination and root development (Banchio, Bogino, Zygadlo, \& Giordano, 2008). Kizil and Toncer (2013) studied the effects of various forms of nitrogen including ammonium nitrate, ammonium sulphate, and diammonium phosphate on some agronomic traits of coneflower in Turkey and annonced that various forms of $\mathrm{N}$ improved agronomic traits such as fresh and dry weights of the root and flowers although ammonium sulphate was relatively better. By Studying on marjoram, Fatma et al. (2006) reported that biological nitrogen fertilizers and phosphate solubilising bacteria could replace chemical types of nitrogen and phosphorus fertilizers for growing this plant. Nagananda et al. (2010) observed that application of biological nitrogen fertilizers improved fenugreek seed germination and its growth. The results of Youssef, Edris, and Gomaa (2004) indicate a better growth and yield in Salvia officinalis by using Azospirillum and Azotobacter species. In the present experiment, the mycorrhizal fungi were able to improve coneflower growth traits and yields compared to the control. The main benefit of mycorrhizal inoculation for the host plant is the extended root zone. The internal 
network of extraradical hyphae functions as an extra link between soil and the plant root system (Sharma \& Adholey, 2004). The increased capacity of mycorrhizal roots as compared to non-mycorrhizal roots is due to the enhanced absorption of elements, especially immobile ones, which are active (Jamal, Ayub, Usman, \& Khan, 2002).

Increased height, root and shoot fresh and dry yield of purple coneflower may be attributed to improved availability of macroelements by the nitrogen-fixing and phosphate solubilising bacteria and mycorrhizal fungi, which provide better conditions for growth and biomass production. Interaction of mycorrhizae and bacteria in soil is very complex to explain and analyse, but in a simply way, their combined application performed better than their sole application. The highest essential oil yield was recorded in plants inoculated with the mixture of the three bacteria. The essential oil belonging to the chemical group of terpenes, which are synthesised via Isopentenyl pyrophosphate (IPP) and dimethylallyl diphosphate (DMAPP), which requires ATP and NADPH. Photosynthesis and its products are directly linked to the production of essential oils. Biological fertilizers such as PGPB and mycorrhizae promote photosynthesis by improving absorption of nutrients, especially $\mathrm{N}$ and $\mathrm{Mg}$, which are crucial in construction and synthesis of chlorophyll. Thus, they improve the production of essential oils (Sangwan, Farooqi, Shabih, \& Sangwan, 2001). According to Abdelaziz, Pokluda, and Abdelwahab (2007) results on Rosmarinus officinalis, enhanced production of essential oils by biological fertilizers can be due to increased number of secretory glands and enhanced monoterpene biosynthesis. Similar results have already been published on Mentha sp. (Ram \& Kumar, 1997) and marjoram (EL-Ghadban, 2002). Berti et al. (2001) concluded that as K increases, echinacoside content also increases in E. angustifolia. El-Sayed et al. (2012) studied the effects of $\mathrm{N}$ and $\mathrm{K}$ on coneflower (Echinacea paradoxa) growth and phytochemical content. They found that the highest level of $\mathrm{N}$ ( $300 \mathrm{~kg} / \mathrm{ha}$ as ammonium sulphate) and $\mathrm{K}(100 \mathrm{~kg} / \mathrm{ha}$ as potassium sulphate) led to the achievement of the highest plant height, flower fresh and dry weights, and total fresh and dry weight. Moreover, the highest polysaccharide, cafeic acid, and alkamide contents were recorded in these plants. Aghaalikhani et al. (2013) in an experiment on the effects of urea fertiliser and biological fertilizers studied yields and phytochemicals of coneflower. Their results showed that the application of biological fertilizers increased the biomass production. The biological fertilizers nitroxin and biophosphere led to the production of the highest leaf dry matter, biological yields, root length, root diameter, stem diameter, and number of lateral stems. Additionally, the highest yield of root phenolics was obtained in these plants. Sayed (2011) studied the effects of biological fertilizers including Azospirillum lipoferum and Bacillus megatherium on growth and phytochemicals of coneflower. Their results indicate that the application of biological fertilizers improves the plant vegetative growth and the contents of carbohydrates and alkamides. Overall, in addition to increasing absorption of nutrients, biological fertilizers improve plant growth and development by biosynthesis of plant hormones, controlling plant pathogens, and some unknown mechanisms.

\section{Conclusions}

Based on the results, the application of PGPR and mycorrhizae improved quantitative and qualitative criteria of purple coneflower. Importantly, the combined application of the bacteria and the fungi was a better treatment than their sole applications. In the combined treatment, either one of these microorganisms might have had a positive effect on the other microorganisms, or they could have had synergistic effects on each other resulted to a better growth and yield. Growth and yield of purple coneflowers inoculated with the mixture of the three bacteria + mycorrhizal inoculum in the first and second year did not have a considerable difference from the chemical fertilizer-treated plants. It is recommended to use biological fertilizers instead of chemical ones so that environmental pollutions could be reduced and the quality of product will be improved.

\section{Acknowledgements}

This work was supported by Research Fund of Cukurova University (Project No: ZF2012D14). The authors would like to gratefully acknowledge all the members of Department of Horticulture, University College of Agriculture and Natural Resources, University of Tehran, for providing the facilities to carry out this work and for their suggestions. In addition, it can be appreciated to Agriculture of Research, Education and Extension Organization (AREEO), Iran, for providing Laboratory facilities.

\section{References}

Abdelaziz, M. E., Pokluda, R., \& Abdelwahab, M. M. (2007). Influence of compost, microorganisms and NPK fertilizer upon growth, chemical composition and essential oil production of Rosmarinus officinalis L. Not. Bot. Horti. Agrobo., 35(1), 86-90.

Abdul-Jaleel, C., Manivannan, P., Sankar, B., Kishorekumar, A., Gopi, R., Somasundaram, R., \& Panneerselvam, R. (2007). Pseudomonas fluorescens enhances biomass yield and ajmalicine production in Catharanthus roseus under water deficit stress. Colloid. Surface, B, 60, 7-11. https://doi.org/10.1016/j.colsurfb.2007.05.012 
Aghaalikhani, M., Iranpour, A., \& Naghdabadi, H. (2013). Yield and phytochemical variation of Echinacea purpurea L. Moench under application of urea and bio fertilizer. Iran. J. Medicin \& Aroma. Plants, 12(46), 121-136.

Arshad, M., \& Frankenberger, W. P. (1993). Microbial Production of Plant Growth Regulators. In F. B. Metting (Ed.), Soil Microbial Ecology-Application in Agricultural and Environmental Management. Marcel Dekker, Inc, New York.

Ashnavar, M., Mohammad Ali, B., \& Akbarpour, V. (2014). Effect of different sources of fertilizers on growth indices and yield of Echinacea purpurea L. J. Agroecol., 6(2), 266-274.

Banchio, E., Bogino, P. C., Santoro, M., Torres, L., \& Zygadlo, J. (2010). Systemic Induction of Monoterpene Biosynthesis in Origanum majoricum by Soil Bacteria. J. Agr. Food. Chem., 58, 650-654. https://doi.org/10.1021/jf9030629

Banchio, E., Bogino, P. C., Zygadlo, J., \& Giordano, W. (2008). Plant growth promoting rhizobacteria improve growth and essential oil yield in Origanum majorana L. Biochem. Syst. Ecol, 36(10), 736-771. https://doi.org/10.1016/j.bse.2008.08.006

Berti, M., Wilckens, R., Fischer, S., \& Hevia, F. (2001). Effect of harvest season, nitrogen, phosphorus and potassium on root yield, echinacoside and alkylamides in Echinacea angustifolia L., Chile. Possibilities and Limitations of Medicinal and Aromatic Plant (Vol. 576, pp. 303-310). Int. Con. Medicin. Aroma. P.

Bodinet, C., Lindequist, U., Teuscher, E., \& Freudenstein, J. (2002). Effect of an orally applied herbal immunomodulator on cytokine induction and antibody response in normal and immunosuppressed mice. Phytomedicine, 9, 606-613. https://doi.org/10.1078/094471102321616418

Cardoso, I. M., \& Kuyper, T. W. (2006). Mycorrhizas and tropical soil fertility. Agr, Ecosys. Environ., 116, $72-84$. https://doi.org/10.1016/j.agee.2006.03.011

Darzi, M. T., Ghalavand, A., Rajali, F., \& Sefidkon, F. (2006). Effect of biofertilizers application on yield and yield components in fennel (Foeniculum vulgare Mill.). Iran. J. Medicin \& Aroma. Plants, 22(4), 276-292.

Chen, R., Nian, H., \& Wu, H. (2007). Effect of nitrogen, phosphorus, and potassium on yield and quality of Echinacea purpurea. Chin. Trad. Herb. Drugs, 38(6), 917.

Earanna, N. (2007). Response of Stevia rebaudiana to Biofertilizers Karnataka. J. Agr. Sci., 20, 616-617.

El-Ghadban, E. A., Ghallab, E. A. M., \& Abdelwahab, A. F. (2002). Effect of organic fertilizer (Biogreen) and biofertilization on growth, yield and chemical composition of Marjoram plants growth under newly reclaimed soil conditions. 2nd Congress of Recent Technologies in Agriculture, 2, 334-361.

El-Sayed, A. A., Shalaby, A. S., El-Hanafy, H., \& El-Razik, T. A. (2012). Effects of Chemical Fertilizers on Growth and Active Constituents of Echinacea paradoxa L. Plants. J. Hortic. Sci. \& Ornament. Plants, 4(2), 125-133.

Fatma, E. M., El-Zamik, I., Tomader, T., El-Hadidy, H. I., Abd El-Fattah, L., \& Seham Salem, H. (2006). Efficiency of biofertilizers, organic and in organic amendments application on growth and essential oil of marjoram (Majorana hortensis L.) plants grown in sandy and calcareous. University and Soil Fertility and Microbiology Department, Desert Research Center, Cairo, Egypt.

Frankenberger, W. T., \& Arshad, M. (1995). Phytohormones in soils microbial production and function. New York: Marcel Dekker Inc.

Freitas, M. S. M., Martins, M. A., \& Vieria, I. J. C. (2004). Yield and quality of essential oils of Mentha arvensis in response to inoculation with AM Fungi. Pesqui. Agropecu. Bras., 39(9), 887-894.

Gupta, M. L., Prasad, A., Ram, M., \& Kumal, S. (2002). Effect of the AM Fungus G. fasciculatum on the essential oil related characters and nutrient acquisition in the crops of different cultivars of menthol mint (Mentha arvensis) under field yield condition. Bioresource Technol., 81, 77-79. https://doi.org/10.1016/S0960-8524 (01)00109-2

Jamal, A., Ayub, N., Usman, M., \& Khan, A. G. (2006). AM Fungi enhance Zinc and Nickle uptake from contaminated soil by soyabean and lentil. Int. J. Phytoremed., 4(3), 205-221. https://doi.org/10.1080/ 15226510208500083 
Kandeel, Y. M., Menesy, F. A., Khalafalla, M. M., \& Gad, W. M. (2004). Effect of some commercial biofertilizers on growth, seed, volatile oil yield and chemical composition of Foeniculum vulgare Mill. J. Agr. Res., 30(3), 721-737.

Kapoor, R., Giri, B., \& Mukerji, K. G. (2002a). Glomus macrocarpum, a potential bioinoculant to improve essential oil quality and concentration in dill (Anethum graveolens L.) and carum (Trachyspermum ammi L. Sprague). World J. Microb. Biotechnol., 18, 459-463. https://doi.org/10.1023/A:1015522100497

Kapoor, R., Giri, B., \& Mukerji, K. G. (2002b). Mycorrhization of coriander (Coriandrum sativum L.) to enhance the concentration and quality of essential oil. J. Sci. Food. Agr., 82, 339-342. https://doi.org/10.1002/ jsfa.1039

Karthikeyan, B., Joe, M. M., \& Cheruth, A. J. (2009). Response of some medicinal plants to vesicular arbuscular mycorrhizal inoculations. J. Sci. Res., 1(2), 381-386.

Khaosaad, T., Vierheilig, H., Nell, M., Zitterl-Eglseer, K., \& Novak, J. (2006). Arbuscular mycorrhiza alters the concentration of essential oils in oregano (Origanum sp., Lamiaceae). Mycorrhiza, 16, 443-446. https://doi.org/10.1007/s00572-006-0062-9

Kizil, S., \& Toncer, O. (2013). Effects of different nitrogen forms on some agronomical characteristics of Echinacea Purpurea. In: Semi-Arid Conditions of Turkey. Sci. Papers. Series A. Agro., LVI, 304-307.

Kumar, V., Singh, A., \& Sharma, S. (2009). Yield and economics of Withania somnifera influenced by dual inoculation of Azotobacter chroococcum and Pseudomonas putida. Turk. J. Biol., 33(3), 219-223.

Malik, A. A., Suryapani, S., \& Ahmad, J. (2011). Chemical vs. Organic Cultivation of Medicinal and Aromatic plants: the choice is clear. Int. J. Med. Arom. Plants, 1(1), 5-13.

Nagananda, G. S., Das, A., Bhattacharya, S., \& Kalpana, T. (2010). In vitro studies on the effects of biofertilizers (Azotobacter and Rhizobium) on seed germination and development of Trigonella foenum-graecum L. using a novel glass marble containing liquid medium. Int. J. Bot., 6, 394-403. https://doi.org/10.3923/ijb.2010. 394.403

Nasir, Z. (2008). Comparison effects of Echinacea purpurea juices and Nigella sativa seeds on performance, some blood parameters, carcass and meat quality of broilers (Ph.D. thesis). Institute of Animal Breeding and Husbandry, University of Hohenheim, Stuttgart.

Ram, M., \& Kumar, S. (1997). Yield improvement in the regenerated and transplanted mint Mentha arvensis by recycling the organic wastes and manures. Bioresource Technol., 59(2), 141-149. https://doi.org/10.1016/ S0960-8524(96)00159-9

Ram, M., Patra, D. D., \& Kumar, S. (1997). Nitrogen fertilization of palmarosa in continuous cropping. J. Herb. Spic. Med. Plants, 5(1), 53-61. https://doi.org/10.1300/J044v05n01_06

Razavinia, S. M., Aghaalikhani, M., \& Naghdabadi, H. (2015). Effect of vermincompost and chemical fertilizer on qualitative and quantititative traits of Echinacea purpurea L. Iran. J. Medicin \& Aroma. Plants, 31(2), 373-357.

Sangwan, N. S., Farooqi, A. H. A., Shabih, F., \& Sangwan, R. S. (2001). Regulation of essential oil production in plants. Plant. Grow. Regul., 34, 3-21. https://doi.org/10.1023/A:1013386921596

Sayed, H. S. A. R. (2011). Response of purple coneflower, Echniacea purpurea L. moench to biofertilization (M.Sc. thesis). Department of Ornamental Horticulture, Faculty of Agriculture, Cairo University.

Shaalan, M. N. (2005). Influence of biofertilizers and chicken manure on growth, yield and seeds quality of (Nigella sativa L.) plants. Egypt. J. Agr. Res., 83, 811-828.

Shalaby, A. S., El-Gengaihi, S. E., Agina, E. A., El-Khayat, A. S., \& Hendawy, S. F. (1997). Growth and yield of Echinacea purpurea L. as influenced by planting density and Fertilization. J. Herb. Spice. Med. Plants, 5(1), 69-76. https://doi.org/10.1300/J044v05n01_08

Sharma, A. K. (2002). Biofertilizers for Sustainable Agriculture. Agrobios, India.

Sharma, M. P., \& Adholey, A. (2004). Effect of AM Fungi and P fertilization on the micro propagated strawberry grown in a sandy loam soil. Can. J. Bot, 82, 322-328. https://doi.org/10.1139/b04-007

Tilak, K. V. B. R., Ranganayak, N., Pal, K. K., De, R., Saxena, A. K., Nautiyal, C. S., ... Johri, B. N. (2005). Diversity of plant growth and soil health supporting bacteria. Curr. Sci. India., 89(1), 136-150. 
Vinutha, T. (2005). Biochemical Studies on Ocimum Species Inoculated with Micorbial Inoculants. University of Agricultural Sciences, GKVK.

Whitefield, L., Richards, A. J., \& Rimmer, D. L. (2004). Effects of mycorrhizal colonization on Trymus polytrichus from heavy contaminated soils in northern England. Mycorrhiza, 14, 47-54. https://oi.org/ 10.1007/s00572-003-0269-y

Youssef, A. A., Edris, A. E., \& Gomaa, A. M. (2004). A comparative study between some Plant growth regulators and certain growth hormones producing microorganisms on Growth and essential oil composition of Salvia officinalis L. Plant. Annal. Agr. Sci, 9, 299-311.

Yousef, R. M., Khalil, S. E., \& El-Said, N. A. (2013). Response of Echinacea purpurea L. to irrigation water regime and biofertilization in sandy soils. World App. Sci. J., 26(6), 771-782.

\section{Copyrights}

Copyright for this article is retained by the author(s), with first publication rights granted to the journal.

This is an open-access article distributed under the terms and conditions of the Creative Commons Attribution license (http://creativecommons.org/licenses/by/4.0/). 